\title{
SOLUTION TO INCESSANT STRIKES AND NON- IMPLEMENTATION OF COLLECTIVE BARGAINING AGREEMENTS: A NIGERIAN PERSPECTIVE
}

\author{
Kelvin N. Agbakwuru* \\ Email: kelvinagbakwuru10@gmail.com \\ $+2348164154366$
}

$\mathrm{PhD}$ Human Resource Management student at Afe Babalola University, Department of Management and Entrepreneurship Studies, College of Social and Management Sciences.

\begin{abstract}
Nigeria is a political entity prone to incessant strikes of which the non-implementation of collective bargaining agreements is a major cause. This study provides a theoretical approach to evaluate the reasons for these incessant strikes and the non-implementation of collective agreements in the Nigerian industrial system. It further proffers solutions to this ongoing menace by recommending that the Federal Government should live by example in the implementation of collective agreements. Also, in the collective bargaining process, parties to an industrial dispute should ensure their propositions are within their capacity for implementation. No party should bring to the table and agree on what is beyond its capacity of implementing. Additionally, the study suggests that there be a review of the Nigerian labour law and Trades Dispute Act so as to ensure it is in tandem with current trends and global best practices.
\end{abstract}

Keywords: Strike, collective bargaining, collective agreement, implementation, independent collective bargaining commission. 
Journal DOI: www.doi.org/10.46654/ij.24889849

Article DOI: www.doi.org/10.46654/ij.24889849.s75524

\subsection{Introduction}

Over the years, the Nigerian industrial relations system has been characterised by numerous industrial disputes. The social partners in the system find it difficult to reach an agreement and even when they do, find it hard to implement the outcome of the agreement. Strike has almost become the order of the day, taking its highest toll on the educational sector in Nigeria (Olakunle, 2011).

Incessant strikes have been a historical problem in Nigeria. Prior to the nation gaining her independence in 1960, strike has always been a serious issue to the Nigerian state. Adavbielle (2015) asserted that the country has been experiencing strike since the $20^{\text {th }}$ century. Wogu (1969) proved her right by identifying strikes that occurred during the pre-independence era of Nigeria. These strikes include: Aba women riot (1929), railway workers' strike (1938), Nigerian union of railway men strike (1941), general strike (1945), UAC employees in yetstrike (1947), coal miners' strike (1949), mercantile workers' strike (1950), and airways workers' union strike (1959); summing up to eight (8) strikes that occurred in the preindependent Nigeria.

As earlier stated, the educational sector has been observed to be the worst hit victim of incessant strikes in Nigeria especially between the Academic Staff Union of Universities (ASUU) and the federal government. The dispute between these two players have occurred for fifteen (15) times, beginning from the year the country transited from military regime to civilian rule - 1999. Subsequent to that year, the country's university education has experienced strikes in the years, 2001, 2002, 2003, 2005, 2006, 2007, 2008, 2009, 2010, 2011, 2013, 2017, 2018 (Wahab, 2018) and 2020.

The cause of strike has always been the issue of unfair working conditions and unfavourable terms of employment. Workers have always embarked on strike when they feel their economic and occupational health securities are threatened. Due to the exploitative nature of owners of means of production, strike has been seen as an efficacious weapon by workers to get employers to meet their demands. Every worker (union) has the right to strike when there is a perceived exploitation.

The right to strike is a vital component of modern industrial society and any society which seeks to become democratic must ensure that right is secured (MacFarlanc, 1981). This is affirmed by Kahn-Freud and Hepple (1972) who asserted that the right to strike is an indispensable feature of a democratic society and the fundamental right of a human being. It serves as a means of putting employers of labour (the federal government in the case of the public sector) in checks and balances concerning the welfare of labour so as to avoid exploitation. When workers are refused the right to strike, they become like a toothless bulldog (Kawugana, 2016). They can only complain but do nothing about their complaints.

With respect to the case of the Federal Government vs. ASUU in Nigeria, the major cause for the incessant strikes in the university education sector is the lackadaisical attitude on the implementation of reached agreement on the part of the government. The government has been known to continually fail on their promises as regards implementing agreements reached from the collective bargaining process. And with the union left with no other option, has always used strike as a weapon of last resort to get the government to fulfilling the demands of the agreement. It is against this backdrop that this study aims at investigating this issue and recommending solutions for a better industrial society. 
It is of course no news that Nigeria is a nation prone to incessant strikes. And this has negatively affected the socio-economic development of the nation. Idoko (2020) revealed that the federal and state governments have incurred a loss of about $\$ 1.5$ trillion to ASUU strikes in the educational sector since 1999 when the country transited from the military regime to civilian rule. This report shows the severe effect strike actions have on the economic development of the country. Moreover, incessant strikes have been reported to have adverse effects on the academic performance of students (Akintoye \& Uhunmwuangho, 2018). This in turn depreciates the quality of graduates churned out by the universities and negatively affects the human capital development of the country.

Despite the collective bargaining mechanism put in place to air the grievances of parties to an industrial dispute (in the case of the federal government vs. ASUU), strikes still continue to occur in the university educational system. The root cause of this is the inability or reluctance of the government to implement agreements reached from the collective bargaining process. This makes the union (ASUU) to always resort to strikes at every time the federal government fails. The problem therefore to tackle is on the part of the government and not the union since it has always been the government that breaches the agreement.

Emanating from the foregoing, the questions therefore are:

(i) What can be done to make the government implement the agreements reached from previous collective bargaining process?

(ii) What can be done by the government to prevent the occurrence of strikes especially in the public sector in the country?

\subsection{Conceptual Clarification \\ 4.1 Concept of Strike}

The literature encompasses numerous definitions of the term "strike". According to Hornby (2001), strike is described as a period when an organized group of employees of a company stops working due to a wage or conditions disagreement. It also means workers' refusal to work as a form of protest against insufficient or poor work conditions (Edinyang \& Ubi, 2013). In the words of Ivancevich and Konopaske (2013), strike is described as an effort on the part of employees to withhold work to make greater concessions at the negotiating table. Okene (2015) sees strike as an intentional halt to work by employees to press their employers to meet their demands. Adavbielle (2015) opined that strike is an act/attitude of a group of people (i.e. they can be either employees or students) to express their discrepancies, with the aim of attracting beneficial answers. It is an end-product of employees' grievances or incongruity between employees and employers (Igbokwe \& Ogbonna, 2018).

Transiting to legal or statutory definitions, section 47 of the Nigerian Trade Disputes Act (Laws of the Federation of Nigeria, 1990) defines strike as "the cessation of work by a body of persons employed acting in combination, or a concerted refusal or a refusal under a common understanding of any number of persons employed to continue to work for an employer in consequence of a dispute, done as a means of compelling their employer or any persons or body of persons employed, to accept or not to accept terms of employment and physical conditions of work".

From the foregoing definitions, three major conditions must be met before an industrial action can be called strike. One of them is the "uniform agreement and convergence of 
workers". Workers must come together and agree about the commencement of an industrial action. The second component is "the stoppage of work". An industrial action is not called strike if there is no temporary hold on work operations. While the third component is "the reason for the industrial action must be as a result of unfavourable terms of employment and work conditions". Work stoppages must be as a result of employees' grievances over poor working conditions (of which could be hazardous to employees' health and safety) and low wages. These are the conditions that must be met for an industrial action to be called strike. Therefore, strike can be defined as the convergence and uniform agreement of workers on the cessation of work in order to tackle unfavourable working conditions and terms of employment.

\subsubsection{Types of Strikes}

Adavbielle (2015) suggested that there are five types of strikes which include: jurisdictional strike, sympathy strike, recognition strike, economic strike and wildcat strike. According to Clark (2012), jurisdictional strike is a consequence of the argument of two unions about which one has the control over a given work type and endeavours to pressurise employer to allocate it to one or the other. This type of strike is not backed up by law as the employer is put in a dilemma between two conflicting unions. Sympathy strike is a strike where a union which has no relationship with the employer of workers under the aggrieved union embark on a strike action in solidarity with workers under the union so as to pressurise the employer to meet the demands of the aggrieved union. Recognition strike is one embarked upon by a union with the purpose of drawing the attention of the employer and general public to them. It is a strike where a union which is less recognised cease work activities so as to make the employer and general public aware of their presence or existence. Economic strike on the other hand, is one that occurs based on the demand for increased wages and better work conditions. It is mostly referred to as "bread and butter" strike (Adavbielle, 2015). Finally, wildcat strike is a type of strike that is embarked upon by some members of a union whose needs or demands still are not met by the outcome of the union's collective bargaining. It is a strike that occurs when the agreement reached by the union with the employer still does not meet the needs and demands of some members of the union. It originates from within a union when workers representatives (leaders of the union) are unable to negotiate in a way that covers the grievances of all members. This as a result triggers the creation of a faction within the union which end up embarking on a strike action so as to draw the attention of the employer to their grievances. It is often perceived as a rebellious strike action.

\subsubsection{Differentiating between Strike, Lockout and Work Stoppages}

Strike as explained above is an industrial action performed by workers or employees of an organisation or industry. Lockout on the other hand, is an industrial action performed by an employer(s). It is a situation where employees are denied entrance into the workplace while work stoppage is the sudden halt in work activities of an organisation. Both strike and lockout are different types of work stoppages. The difference in them is the purpose for the stoppage of work.

\subsection{Concept of Collective Bargaining}

Collective bargaining has been defined in different ways by various scholars. Olalede (n.d.) defined it as the process whereby the working conditions and employment terms are negotiated between an employer or a group of employers on one side, and one or more 
representatives of unions on the other hand. It is a negotiating and concluding process of collective agreements regarding workers' demands on improvements in employment terms and working conditions (Okene, 2011). Olulu and Udeorah (2018) defined it as group negotiations between the employer and employee on issues concerning their situations of work. From these definitions, collective bargaining can be seen as a negotiation process between employers and employees through which collective agreements are reached on issues related to work.

\subsection{Conclusion and Recommendations}

This study therefore concludes that solution to the incessant strikes in Nigeria majorly lies in the hands of the government. The government as the largest employer of labour needs to understand that it has to serve as a good example for other employers in the industrial system to follow. Also, the government has to awake from its slumber and take the issue of industrial harmony very seriously. The productivity of a nation is contingent upon the output generated by its workforce and if its workforce ceases to work, such nation can plunge into recession. A typical example is the social and economic cost implications of the continuous ASUU strike on the economy. The revenue lost during the period of this industrial action could have contributed to the GDP of the country and help in servicing some debts owed by the country.

It is also pertinent to note that the non-implementation of agreements portrays a bad image of the government. This shows that the government is insensitive to the needs of the people and is one that lacks integrity. This reduces trust of the citizenry in the government and could affect the re-election of such administration or party in a forthcoming election. Hence, it is imperative for the government to approach the issue of industrial unrest with a proactive approach rather than a reactionary approach.

Consequent upon the foregoing, it is therefore recommended that:

(i) Since the government has not been acting with fidelity on collective agreements reached, it is expedient for the setup of an independent collective bargaining commission that ensures collective agreements reached are implemented by parties to a dispute. In this case, all parties to a collective agreement including the government should be subject to this commission.

(ii) Government should always ensure that every agreement had in previous times with the union (in this case, ASUU) should always be implemented. No excuse should be tolerated for the non-implementation of agreements. It is on this basis that the government can stand as an umpire to ensure that agreements between other partners in the industrial relations system (employer/management and workers) are implemented.

(iii) Unions on the other hand should consider the financial capacity of their employers when making their demands. They should be sure that their employers have the wherewithal to meet the demands they make before requesting it.

(iv) There should be a repealing and replacing of the current Nigerian labour law. The Nigerian labour law is almost obsolete and not in tandem with current trends in the Nigerian industrial society. A new law which addresses the issue of breach of collective agreements should be implemented and strictly enforced beginning from the government. Any party responsible for the breach in collective agreements should be severely penalised. 
(v) While in the collective bargaining process, employers (government inclusive) should ensure the agreements they are reaching are implementable. They should not agree to do what is beyond their capacity at a given time.

(vi) There should be a review of the minimum wage policy as per the current inflation rate in the country. This will ensure that citizens' purchasing power is not affected by the escalating prices of goods and services. When the economic welfare of the citizens are well taken care of in advance, there would be no need for the citizens (who are mostly workers and union members) to organise and embark on a strike. 


\section{References}

Adavbielle, J. (2015). Implications of incessant strike actions on the implementation of technical education programme in Nigeria. Journal of Education and Practice, 6 (8), 134-138.

Akintoye, E. \&Uhunmwuangho, S.O. (2018). Analysis of the effects of frequent strikes on academic performance of students in universities in Nigeria: Edo State as a focal point. African Journals Online, 12 (1).

Clark, A. (2012). Business management. Suffolk: Arima Publishing.

Edinyang, S. \& Ubi, I.E. (2013). Effect of strike action on human development among social studies secondary school students in Uyo local government area of Akwa Ibom State, Nigeria. Global Journal of Human Resource Management, 1 (2), 1-8.

Hornby, A. (2001). Oxford advanced learner's dictionary (6th ed.). New York: Oxford University.

Idoko, C. (2020, October 5). How FG, states lost N1.5 trillion to ASUU strikes: Investigation. Retrieved March 30, 2021, from Nigerian Tribune: https://tribuneonlineng.com/howfg-states-lost-n1-5-trillion-to-asuu-strikes-investigation/

Igbokwe, U. \& Ogbonna, I.L. (2018). Influence of incessant strikes on teachers' professional training: The university of Nigeria experience. International Journal of Applied Engineering Research, 13 (21), 15047-15055.

Ivacenevich, J. \& Konopaske, R. (2013). Human resource management. New York: McGrawHill.

Kawugana, A. (2016). The impact of incessant strikes on the education sector in Nigeria. International Journal of Education and Evaluation, 2 (5), 67-72.

Laws of the Federation of Nigeria. (1990). Trade Dispute Act.

MacFarlanc, L. (1981). The right to strike. London: Penguin Books.

Okene, O. (2015, March 27). The status of the right to strike in Nigeria: A perspective from international and comparative law. Retrieved March 29, 2021, from ResearchGate: https://www.researchgate.net/publication/250228471_The_Status_of_the_Right_to_St rike_in_Nigeria_A_Perspective_from_International_and_Comparative_Law/link/551 4e40a0cf283ee0838ef77/download

Okene, O.V.C. (2011). Labour law in Nigeria: The law of work. Claxton \& Derrick.

Oladele, O. (n.d.). Human resource management in Nigeria. Ado-Ekiti: Ekiti State University.

Olulu, R.M., \&Udeorah, S.A. (2018).The principle of collective bargaining in Nigeria and International Labour Organisation (ILO) standards.International Journal of Research and Innovation in Social Science, 2(4), 63-67. 
Wahab, B. (2018, May 11). All the times ASUU has gone on strike since 1999. Retrieved March 30, 2021, from Pulse.ng: https://www.pulse.ng/communities/student/all-thetimes-asuu-has-gone-on-strike-since-1999/5jtb8cs

Wikipedia. (2021). Lockout (Industry). Retrieved March 30, 2021, from Wikipedia: https://en.wikipedia.org/wiki/Lockout_(industry)\#cite_note-1 